\title{
Optimizing Operating Conditions for Advanced Treatment of Landfill Leachate Using the Coagulation-Fenton Oxidation Method
}

\author{
Guanghui Bu, Ping Xian*, Longhui Zhan, Xiaojuan Feng, Haifang Tang \\ School of Environment, Guangxi University, \\ Nanning 530004, Guangxi Zhuang Autonomous Region, China
}

Received: 29 February 2016

Accepted: 8 May 2016

\begin{abstract}
High COD concentrations in effluent, high membrane loading, and frequent congestion on the membrane are three common shortcomings of treating landfill leachate using the biodegradation technique. Accordingly, advanced treatment of the bio-chemical effluent of landfill leachate by Fenton oxidation combined with coagulation technique were performed in this study. The experiment was designed with the response surface method (RSM) considering three factors, i.e., the dosages of polymeric ferric sulfate (PFS), $\mathrm{n}\left(\mathrm{H}_{2} \mathrm{O}_{2}\right) /$ $\mathrm{n}\left(\mathrm{Fe}^{2+}\right)$, and $\mathrm{H}_{2} \mathrm{O}_{2}$. Experimental results show that the fitting curve has high significance and sensitivity, and the prediction error of the COD removal rate is smaller than $\pm 5 \%$. The results also show that $\mathrm{H}_{2} \mathrm{O}_{2}$ has the greatest influence on COD removal rate, while PFS has the smallest. The optimal operating conditions for landfill leachate with a COD concentration of $2,000 \mathrm{mg} / 1$ are: the dosages of PFS (the concentration is $0.05 \mathrm{~g} / \mathrm{ml})$, and $\mathrm{H}_{2} \mathrm{O}_{2}(30 \%)$ and $\mathrm{n}\left(\mathrm{H}_{2} \mathrm{O}_{2}\right) / \mathrm{n}\left(\mathrm{Fe}^{2+}\right)$ are $67 \mathrm{ml}, 17 \mathrm{ml}$, and 6 respectively. The optimized COD removal rate can reach as high as $92.11 \%$.
\end{abstract}

Keywords: fenton oxidation, coagulation, response surface analysis, landfill leachate

\section{Introduction}

As municipal solid waste increases annually, the leachate would have a significant impact on the steady running of the landfill [1-5]. The biological method is the main processing technique in most landfills and the membrane module is an advanced treatment technique. However, with the passage of time the accumulation of toxic and hazardous substances would lead to a decrease of biodegradability and processing capacity, increase membrane loading, and reduce treatment efficiency [6-
7]. Physicochemical methods, including coagulation and Fenton-oxidation, are now applied widely in advanced biological processing or membrane pretreatment [8-10]. The organics and heavy metals in the leachate could be effectively reduced with the coagulation method, and the biodegradability of the refractory organics could be improved with the Fenton-oxidation method [11-12]. The stability of leachate quality in the effluent could be guaranteed with their combination. However, in the current combination of coagulation-Fenton oxidation, in which the two reactions are regarded as two independent processes [13], the dosage as well as the cost is high, leading to low economic benefit [14-16]. This study uses 
the coagulation-Fenton oxidation method between the biological treatment and the membrane treatment, which could reduce the dosage of reagents, optimize the effluent, and reduce the membrane load. Treating the coagulationFenton oxidation as one process and considering the effects of PFS on the Fenton process, the Box-Behnken experiments design (BBD) [17] test, and the response surface method (RSM) is used to optimize the operating conditions.

\section{Materials and Methods}

\section{Characteristics of the Leachate}

The leachate was collected from effluent of the biochemically treated leachate from a landfill in Nanning, Guangxi, and its characteristics are shown in Table 1. The origins of reagents in this study are shown in Table 2.

\section{Testing Methods}

Employing the software package Design-Expert (v. 8.0.5b), a three-factor (PFS $(\mathrm{ml}), \mathrm{n}\left(\mathrm{H}_{2} \mathrm{O}_{2}\right) / \mathrm{n}\left(\mathrm{Fe}^{2+}\right)$, $\mathrm{H}_{2} \mathrm{O}_{2}(\mathrm{ml})$ ) three-level Box-Behnken experiments design (BBD) was performed with COD removal rate as the target response value. The response of the interaction of the factors to the COD removal rate is determined by fitting

Table 1. Characteristics of the leachate before processing.

\begin{tabular}{|c|c|}
\hline Item & Value \\
\hline $\mathrm{pH}$ & $8.00-9.00$ \\
\hline $\mathrm{COD}(\mathrm{mg} / \mathrm{l})$ & $2300-2500$ \\
\hline $\mathrm{NH}_{3}-\mathrm{N}(\mathrm{mg} / \mathrm{l})$ & $1,300-1,600$ \\
\hline $\mathrm{SO}_{4}{ }^{2-}(\mathrm{mg} / \mathrm{l})$ & $90.05-92.10$ \\
\hline $\mathrm{Cl}^{-}(\mathrm{mg} / \mathrm{l})$ & $1,400-1,800$ \\
\hline Alkalinity $(\mathrm{mg} / \mathrm{l})$ & $4,015-4,428$ \\
\hline Chromaticity & 512 \\
\hline
\end{tabular}

the response surface model to predict the best operating conditions for the landfill leachate treated with the Fenton oxidation-coagulation method.

The three-level values are -1 (lower level), 0 (middle level), and 1 (upper level). Single factor experimental results show that the optimized dosage of $\mathrm{PFS}(\mathrm{ml})$, $\mathrm{n}\left(\mathrm{H}_{2} \mathrm{O}_{2}\right) / \mathrm{n}\left(\mathrm{Fe}^{2+}\right)$, and $\mathrm{H}_{2} \mathrm{O}_{2}(\mathrm{ml})$ are $10-20 \mathrm{ml}, 1-7$, and 0.5-5 ml, respectively (Table 3 ).

The samples were divided into three groups according to the sequence numbers (1-6, 7-12, 13-17) and one group was tested at one time. For each test, $2.5 \mathrm{~L}$ landfill leachate was used and the $\mathrm{pH}$ value was adjusted to 5-6 with $\mathrm{H}_{2} \mathrm{SO}_{4}$ and $\mathrm{NaOH}$ solutions. After $450 \mathrm{ml}$ leachate was added into six $500 \mathrm{ml}$ beakers, respectively, PFS was added into each beaker and the dosage was set according to Table 4 . Then the beakers were stirred slowly by a synchronous electrical stirrer for $20 \mathrm{~min}$ and standing for $1 \mathrm{~h}$. Then $300 \mathrm{ml}$ supernatant in each beaker was taken and added into another $500 \mathrm{ml}$ beaker. The $\mathrm{pH}$ value was adjusted to 3.0 with $\mathrm{H}_{2} \mathrm{SO}_{4}, \mathrm{FeSO}_{4} \cdot 7 \mathrm{H}_{2} \mathrm{O}$, and $\mathrm{H}_{2} \mathrm{O}_{2}$, whose amounts were determined according to Table 4 , added into the beakers, and then stirred again at medium speed for $5 \mathrm{~h}$. When the reaction was over, the $\mathrm{pH}$ values of the samples in the six beakers were adjusted to 7.0. After standing, the supernatant was taken out and tested for COD with dichromate titration [18].

\section{Results and Discussion}

\section{Regression Model Analysis}

Response surface analysis was performed with DesignExpert and the experimental data were fitted with standard polynomials. The results are shown in Fig. 1, and the fitted polynomial is as follows:

$$
\begin{gathered}
\mathrm{Y}(\%)=67.242+0.077 \mathrm{~A}+3.374 \mathrm{~B}+ \\
3.524 \mathrm{C}-0.017 \mathrm{AB}+0.029 \mathrm{AC}+0.500 \mathrm{BC} \\
+(5.600 \mathrm{E}-003) \mathrm{A}^{2}-0.457 \mathrm{~B}^{2}-0.649 \mathrm{C}^{2}
\end{gathered}
$$

As seen from Figs 1a) and b), the relative errors and residuals are both very small. Also, the residual data are

Table 2. Experiment reagents.

\begin{tabular}{|c|c|c|}
\hline Reagent & Grade & Origin \\
\hline $30 \% \mathrm{H}_{2} \mathrm{O}_{2}$ & GR & Chinese Medicine Group Chemical Reagent Co., Ltd \\
\hline $\mathrm{FeSO}_{4} \cdot 7 \mathrm{H}_{2} \mathrm{O}$ & AP & Guangdong Engineering Technology Research Center For Chemical Reagent \\
\hline $\mathrm{PFS}$ & AP & Tianjin Damao Chemical Reagent Company \\
\hline Potassium dichromate & AP & Chengdu Kelong Chemical Reagent Company \\
\hline$\left(\mathrm{NH}_{4}\right)_{2} \mathrm{Fe}\left(\mathrm{SO}_{4}\right)_{2} \cdot 6 \mathrm{H}_{2} \mathrm{O}$ & AP & Guangdong Guanghua Science and Technology Co., LTD \\
\hline $\mathrm{H}_{2} \mathrm{SO}_{4}$ & AP & Guangdong Shantou Xilong Chemical Engineering Co., Ltd \\
\hline$\left[\mathrm{SO}_{4}\right]^{2-}$ & AP & Shanghai Shenbo Chemical Engineering Co., Ltd \\
\hline $1,10-$ Phenanthroline monohydrate & AP & Tianjin Damao Chemical Reagent Company \\
\hline
\end{tabular}


Table 3. Independent variables and levels for the BBD design.

\begin{tabular}{|c|c|c|c|}
\hline \multirow{2}{*}{ Factor } & \multicolumn{3}{|c|}{ Level value } \\
\cline { 2 - 4 } & -1 & 0 & 1 \\
\hline PFS X $1(\mathrm{ml})$ & 10 & 15 & 20 \\
\hline $\mathrm{n}_{(}\left(\mathrm{H}_{2} \mathrm{O}_{2}\right) / \mathrm{n}\left(\mathrm{Fe}^{2+}\right) \mathrm{X}_{2}$ & 1 & 4 & 7 \\
\hline $\mathrm{H}_{2} \mathrm{O}_{2} \mathrm{X}_{3}(\mathrm{ml})$ & 0.5 & 2.75 & 5 \\
\hline
\end{tabular}

distributed symmetrically along a line and they are dense in the middle while sparse at either end, indicating a normal distribution characteristic. The $\mathrm{p}$ value is 0.0682 , which is not significant $(>0.05)$, indicating that the fitted polynomial can be used in the following analysis instead of the real experimental data.

Table 5 shows the analysis of variance (ANOVA) results, with $\mathrm{F}$ and $\mathrm{p}$ values being parameters that indicate the significance level of the model. If $\mathrm{p}$ value is greater than 0.1 , the influence of the factor on the response value is not significant, and vice versa [19-20]. We can see in Table 5 that for COD removal rate the linear terms of the independent variables $B(p=0.04<0.04), C(p=0.0011$ $<0.0011)$, the quadratic terms BC $(\mathrm{p}=0.0498<0.0498)$, and $\mathrm{B} 2(\mathrm{p}=0.0212<0.05)$ are significant items. Thus we can conclude that in the advanced treatment of landfill leachate with Fenton oxidation-coagulation method, the

Table 4. Three-factor and three-level BBD design and experimental results

\begin{tabular}{|c|c|c|c|c|}
\hline \multirow{2}{*}{ Number } & \multicolumn{3}{|c|}{ Experimental design } & $\begin{array}{c}\text { COD removal } \\
\text { rate } \\
(\%)\end{array}$ \\
\cline { 2 - 5 } & $\begin{array}{c}\text { PFS } \\
(\mathrm{ml})\end{array}$ & $\begin{array}{c}\left.\mathrm{n}_{2} \mathrm{H}_{2}\right) / \\
\mathrm{n}\left(\mathrm{Fe}^{2+}\right)\end{array}$ & $\begin{array}{c}\mathrm{H}_{2} \mathrm{O}_{2} \\
(\mathrm{ml})\end{array}$ & 84.3 \\
\hline 1 & 10 & 7 & 2.75 & 87.6 \\
\hline 2 & 20 & 7 & 2.75 & 75.4 \\
\hline 3 & 10 & 4 & 0.50 & 91.6 \\
\hline 4 & 20 & 4 & 5.00 & 73.7 \\
\hline 5 & 15 & 7 & 0.50 & 76.6 \\
\hline 6 & 10 & 1 & 2.75 & 87.9 \\
\hline 7 & 15 & 4 & 2.75 & 83.9 \\
\hline 8 & 15 & 4 & 2.75 & 86.5 \\
\hline 9 & 15 & 4 & 2.75 & 76.1 \\
\hline 10 & 20 & 4 & 0.50 & 80.9 \\
\hline 11 & 20 & 1 & 2.75 & 87.8 \\
\hline 12 & 15 & 4 & 2.75 & 89.6 \\
\hline 13 & 10 & 4 & 5.00 & 85.5 \\
\hline 14 & 15 & 4 & 2.75 & 77.5 \\
\hline 15 & 15 & 1 & 0.50 & 87.1 \\
\hline 16 & 15 & 7 & 5.00 & 5.00 \\
\hline 17 & 15 & 1 & 5 & \\
\hline
\end{tabular}

factors influencing the COD removal are ordered as, $\mathrm{H}_{2} \mathrm{O}_{2}(\mathrm{ml})>\mathrm{n}\left(\mathrm{H}_{2} \mathrm{O}_{2}\right) / \mathrm{n}\left(\mathrm{Fe}^{2+}\right)>$ PFS $(\mathrm{ml})$. Increasing the doses of $\mathrm{H}_{2} \mathrm{O}_{2}$ and increasing $\mathrm{n}_{2}\left(\mathrm{H}_{2} \mathrm{O}_{2}\right) / \mathrm{n}\left(\mathrm{Fe}^{2+}\right)$ are more effective for the degradation of organic matter, while increasing PFS is not. The reason is that with the increase of $\mathrm{n}\left(\mathrm{H}_{2} \mathrm{O}_{2}\right) / \mathrm{n}\left(\mathrm{Fe}^{2+}\right)$, more $\cdot \mathrm{OH}$ will be produced, which can increase the reaction rate, enhance the capacity of oxidation, degrade the organic matter efficiently, and greatly improve the removal rate of COD. While for PFS, which is a composite coagulation made up of elemental iron or iron oxide and other iron compounds, the PFS remaining in the water after coagulation has little effect on $\mathrm{Fe}^{2+}$ content.

Unlike $\mathrm{p}$ value, the greater the $\mathrm{F}$ value, the more significant the effects of the factor on the response value. In this ANOVA analysis, $F=6.36$ and $p<0.0117$, indicating that the model has a high significance in prediction of COD removal rate. The adjusted $\mathrm{R}^{2}$ coefficient (adj) is $0.8910(>0.80)$ and the coefficient of variation $(\mathrm{CV})$ is $3.44 \%$, indicating that the model has a variation of $10.9 \%$, which could be explained by the model. The signal-tonoise ratio is $8.003(>4)$, showing that the experimental results can be well represented by the model. The above indicators further indicate that the fitting is relatively good and can be used to analyze and predict treating landfill leachate with the Fenton oxidation-coagulation method.

\section{Response Surface Analysis}

Response surfaces graphs and contour plots between various factors and response values can be obtained according to the respective regression equations. The response surface graph is a three-dimensional curved surface of each factor, and the steeper the surface, the greater the influences of the factors on the response values. The contour plot reflects the interaction intensity of the various factors. The oval indicates a significant interaction between two factors while the circle indicates that the interaction intensity is not significant [21].

\section{Effects of $\mathrm{n}\left(\mathrm{H}_{2} \mathrm{O}_{2}\right) / \mathrm{n}\left(\mathrm{Fe}^{2+}\right)$ and PFS on COD Removal Rate}

The effects of $\mathrm{n}\left(\mathrm{H}_{2} \mathrm{O}_{2}\right) / \mathrm{n}\left(\mathrm{Fe}^{2+}\right)$ and PFS as well as the interaction on $\mathrm{COD}$ removal rate are shown in Fig. 2, where we can see that when $\mathrm{n}\left(\mathrm{H}_{2} \mathrm{O}_{2}\right) / \mathrm{n}\left(\mathrm{Fe}^{2+}\right)$ is between 1.00 and 5.00, the COD removal rate increases significantly with the increase of $\mathrm{n}\left(\mathrm{H}_{2} \mathrm{O}_{2}\right) / \mathrm{n}\left(\mathrm{Fe}^{2+}\right)$. When $\mathrm{n}\left(\mathrm{H}_{2} \mathrm{O}_{2}\right) / \mathrm{n}\left(\mathrm{Fe}^{2+}\right)$ is greater than 5.00, the COD removal rate decreases when $\mathrm{n}\left(\mathrm{H}_{2} \mathrm{O}_{2}\right) / \mathrm{n}\left(\mathrm{Fe}^{2+}\right)$ increases. This is because in the process of the Fenton reaction, the concentrations of $\mathrm{H}_{2} \mathrm{O}_{2}$ and $\mathrm{Fe}^{2+}$ will directly influence the oxidation of organic compounds. When $\mathrm{Fe}^{2+}$ is constant and in excess, the oxidation of organic matter will increase since the concentration of the hydroxyl radical participated in the reaction increases with the increase of $\mathrm{n}\left(\mathrm{H}_{2} \mathrm{O}_{2}\right) / \mathrm{n}\left(\mathrm{Fe}^{2+}\right)$. However, when the concentration of $\mathrm{H}_{2} \mathrm{O}_{2}$ is far higher than that of $\mathrm{Fe}^{2+}$, the hydroxyl radicals generated with the Fenton method would react with $\mathrm{H}_{2} \mathrm{O}_{2}$, produce 
a)

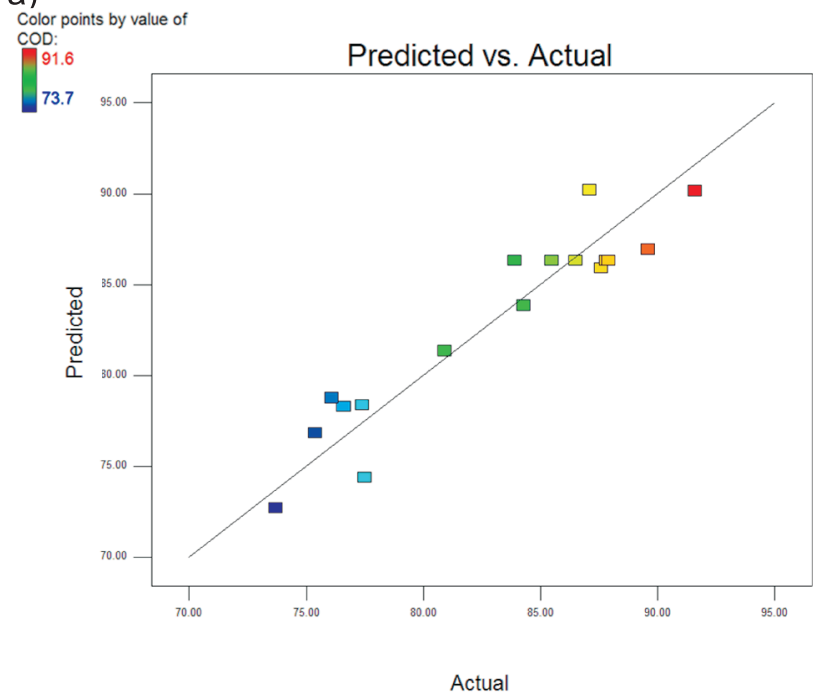

b)

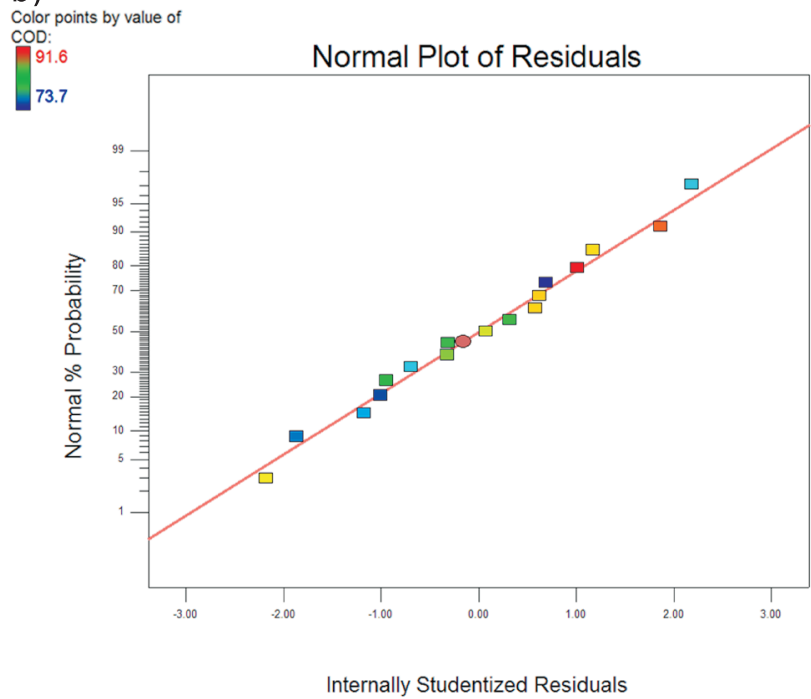

Fig. 1. The experimental results and the fitting line a), the distribution of the residuals for $\mathrm{Yb}$ ).

$\mathrm{HO}_{2}$, and trigger a series of reactions. In addition, $\mathrm{Fe}^{3+}$ will react with $\mathrm{HO}_{2} \cdot$ and produce $\mathrm{O}_{2} \mathrm{H}^{+}$, leading to a high consumption of $\mathrm{H}_{2} \mathrm{O}_{2}$ and a decrease of the COD removal rate [22]. The maximum removal rate of COD is obtained when $\mathrm{n}\left(\mathrm{H}_{2} \mathrm{O}_{2}\right) / \mathrm{n}\left(\mathrm{Fe}^{2+}\right)$ equals 5.00 .

When the dosage of PFS increases from $10 \mathrm{ml}$ to 20 $\mathrm{ml}$ gradually, the COD removal rate increases slowly but not significantly. The reason is that PFS is added in the coagulation stage, in which only a small amount of COD will be removed and part of the organic matters will be adsorbed and coagulated, leading to a small increase in the COD removal rate [23]. It can also be seen from Fig. 2 that the influences of $\mathrm{n}\left(\mathrm{H}_{2} \mathrm{O}_{2}\right) / \mathrm{n}\left(\mathrm{Fe}^{2+}\right)$ on COD removal rate are more significant than PFS. The effects of the interaction between $\mathrm{n}\left(\mathrm{H}_{2} \mathrm{O}_{2}\right) / \mathrm{n}\left(\mathrm{Fe}^{2+}\right)$ and PFS on COD removal rate is insignificant. Therefore, in the laboratory it is an effective way to increase COD removal rate by increasing $\mathrm{n}\left(\mathrm{H}_{2} \mathrm{O}_{2}\right)$ / $\mathrm{n}\left(\mathrm{Fe}^{2+}\right)$.

\section{Effects of $\mathrm{H}_{2} \mathrm{O}_{2}$ and PFS on COD Removal Rate}

The effects of $\mathrm{H}_{2} \mathrm{O}_{2}$ and PFS on COD removal rate are shown in Fig. 3, which shows that with the increase of

Table 5. ANOVA for COD removal rates.

\begin{tabular}{|c|c|c|c|c|c|}
\hline Source & Sum of square (SS) & Degree of freedom & Mean square & F value & $p$ value \\
\hline Model & 465.33 & 9 & 51.70 & 6.36 & 0.0117 \\
\hline $\mathrm{A}-\mathrm{PFS}$ & 13.26 & 1 & 13.26 & 1.63 & 0.2422 \\
\hline $\mathrm{B}-\mathrm{n}\left(\mathrm{H}_{2} \mathrm{O}_{2}\right) / \mathrm{n}\left(\mathrm{Fe}^{2+}\right)$ & 51.51 & 1 & 51.51 & 6.34 & 0.0400 \\
\hline $\mathrm{C}-\mathrm{H}_{2} \mathrm{O}_{2}$ & 231.12 & 1 & 231.12 & 28.43 & 0.0011 \\
\hline $\mathrm{AB}$ & 0.25 & 1 & 0.25 & 0.031 & 0.8658 \\
\hline $\mathrm{AC}$ & 0.42 & 1 & 0.42 & 0.052 & 0.8262 \\
\hline $\mathrm{BC}$ & 45.56 & 1 & 45.56 & 5.61 & 0.0498 \\
\hline $\mathrm{A}^{2}$ & 0.083 & 1 & 0.083 & 0.010 & 0.9226 \\
\hline $\mathrm{B}^{2}$ & 71.12 & 1 & 71.12 & 8.75 & 0.0212 \\
\hline $\mathrm{C}^{2}$ & 45.44 & 7 & 85.44 & 5.59 & 0.0500 \\
\hline Residual error & 56.90 & 3 & 15.22 & 5.41 & 0.0682 \\
\hline Lack of fit & 45.65 & 4 & 2.81 & & \\
\hline Pure error & 11.25 & 16 & & & \\
\hline Total error & 522.23 & & & \\
\hline
\end{tabular}


a)

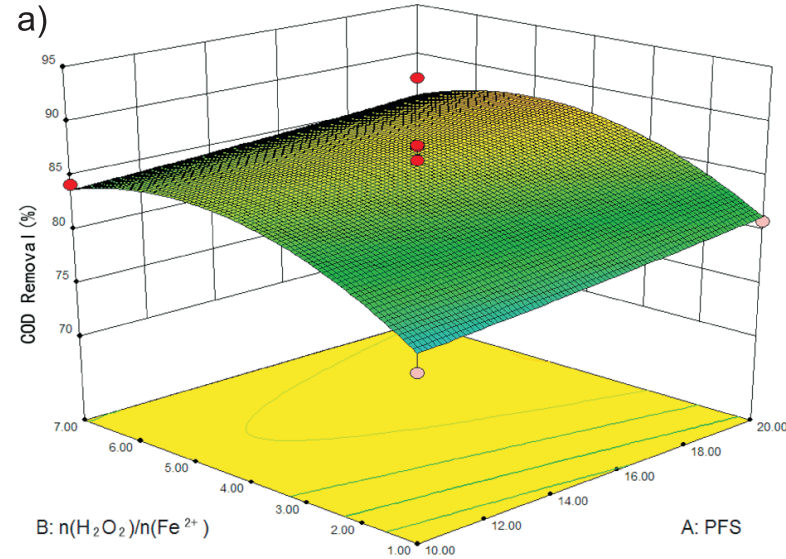

b)

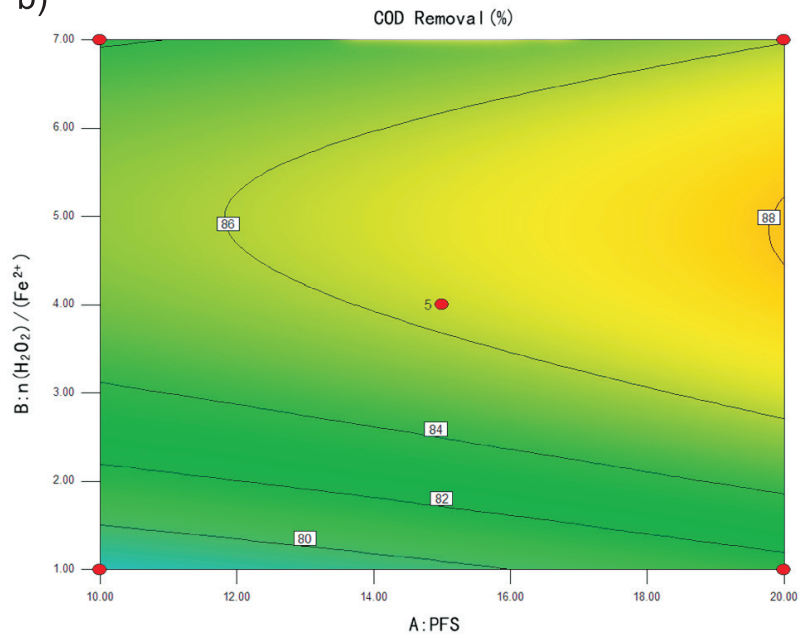

Fig. 2. Effects of $n\left(\mathrm{H}_{2} \mathrm{O}_{2}\right) / n\left(\mathrm{Fe}^{2+}\right)$ a) and PFS b) as well as their interaction on $\mathrm{COD}$ removal rate.

$\mathrm{H}_{2} \mathrm{O}_{2}$ dosage, the COD removal rate increases significantly and the $\mathrm{H}_{2} \mathrm{O}_{2}$ surface is steeper. The maximum COD removal rate is obtained when the $\mathrm{H}_{2} \mathrm{O}_{2}$ dosage is $4.5 \mathrm{~mL}$. But when the $\mathrm{H}_{2} \mathrm{O}_{2}$ dosage is greater than $4.5 \mathrm{ml}$, the COD removal rate decreases gradually. The reason is that when the amount of $\mathrm{H}_{2} \mathrm{O}_{2}$ is small, the corresponding amount of hydroxyl is small and the oxidation of organic matter is less, leading to a low COD removal rate. When $\mathrm{H}_{2} \mathrm{O}_{2}$ gradually increases, the hydroxyl will increase, leading to a high COD removal rate. When the amount of $\mathrm{H}_{2} \mathrm{O}_{2}$ is greater than $4.5 \mathrm{ml}, \mathrm{Fe}^{2+}$ will be oxidized to $\mathrm{Fe}^{3+}$ by the excessive $\mathrm{H}_{2} \mathrm{O}_{2}$, leading to a low effective utilization rate of $\mathrm{H}_{2} \mathrm{O}_{2}$. Besides, $\mathrm{Fe}^{3+}$ would inhibit the production of $\cdot \mathrm{OH}$ ${ }^{[24]}$ and the COD removal rate decreases. Therefore, the changes of $\mathrm{H}_{2} \mathrm{O}_{2}$ will have significant influences on the COD removal rate. In the process of the Fenton reaction, the concentration of $\mathrm{H}_{2} \mathrm{O}_{2}$ will directly influence the oxidation of organic compounds. The oxidation of organic matters will increase with the increase of $\mathrm{H}_{2} \mathrm{O}_{2}$ dosage.

With the increase of PFS, the COD removal rate increases slowly, but not significantly, because with the increase of PFS, multi-charged polymeric ions promote the aggregation of leachate colloid, leading to an increase
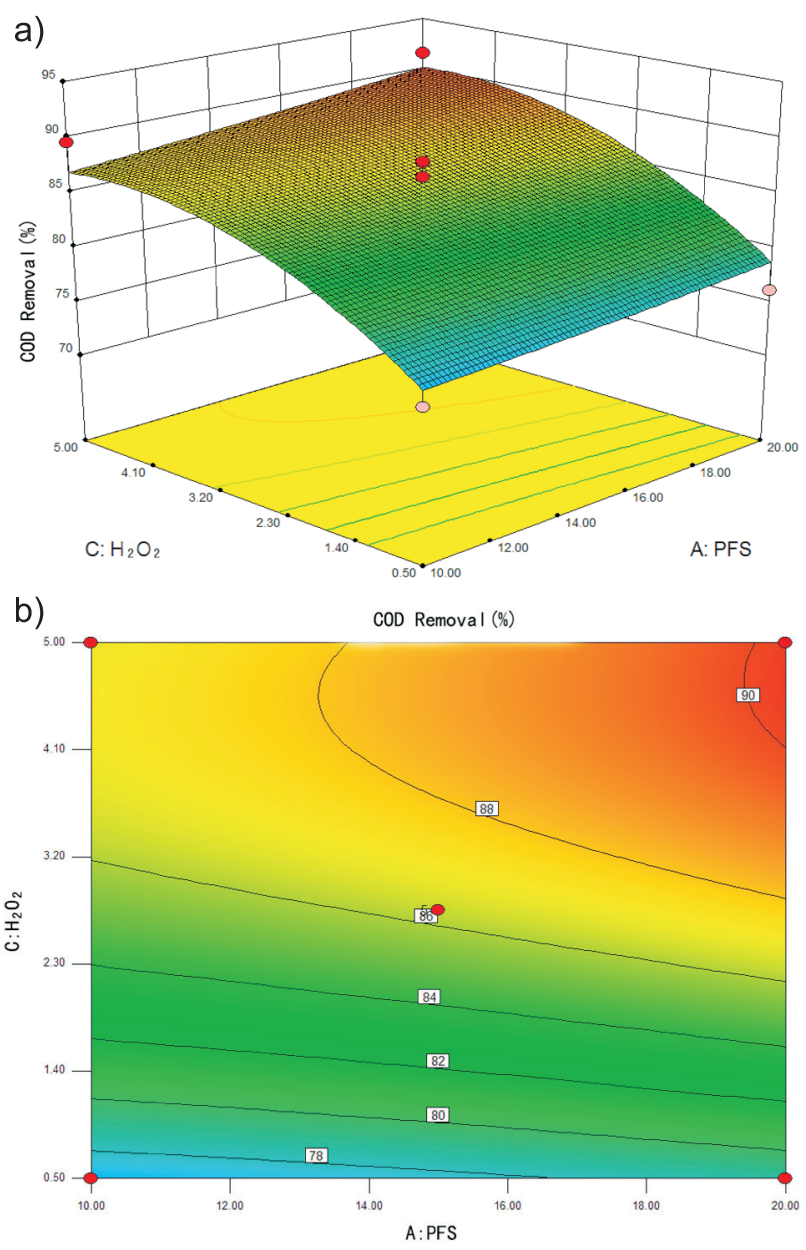

Fig. 3. Effects of $\mathrm{H}_{2} \mathrm{O}_{2}$ a) and PFS b) as well as their interaction on $\mathrm{COD}$ removal rate.

in the COD removal rate. But excessive PFS re-stabilized the agglomerated colloid, leading to a decrease in the COD removal rate [25]. Therefore, increasing the COD removal rate by increasing the PFS dosage is not obvious [26], while increasing $\mathrm{H}_{2} \mathrm{O}_{2}$ is obvious. The effects of the interaction between $\mathrm{H}_{2} \mathrm{O}_{2}$ and PFS on COD removal rate is not significant. Therefore, in the laboratory it's an effective way to increase COD removal rate by increasing $\mathrm{H}_{2} \mathrm{O}_{2}$.

$$
\begin{gathered}
\text { Effects of } \mathrm{H}_{2} \mathrm{O}_{2} \text { and } \mathrm{n}\left(\mathrm{H}_{2} \mathrm{O}_{2}\right) / \mathrm{n}\left(\mathrm{Fe}^{2+}\right) \\
\text { on COD Removal Rate }
\end{gathered}
$$

The effects of $\mathrm{H}_{2} \mathrm{O}_{2}$ and $\mathrm{n}\left(\mathrm{H}_{2} \mathrm{O}_{2}\right) / \mathrm{n}\left(\mathrm{Fe}^{2+}\right)$ as well as their interaction on the COD removal rate are shown in Fig. 4. As seen from Fig. 4, the COD removal rate firstly increases with the increase of $\mathrm{H}_{2} \mathrm{O}_{2}$ dosage, and then tends to be flat in the end. The reason is that with the increase of $\mathrm{H}_{2} \mathrm{O}_{2}$, the hydroxyl radicals increase, the oxidation ability also gradually increases, and the degradation of organic matter increases gradually but significantly. However, when the dosage of $\mathrm{H}_{2} \mathrm{O}_{2}$ is greater than or equal to $4.5 \mathrm{ml}$, though the hydroxyls increase, some organic matter cannot be degraded by hydroxyl radical oxidation 
a)

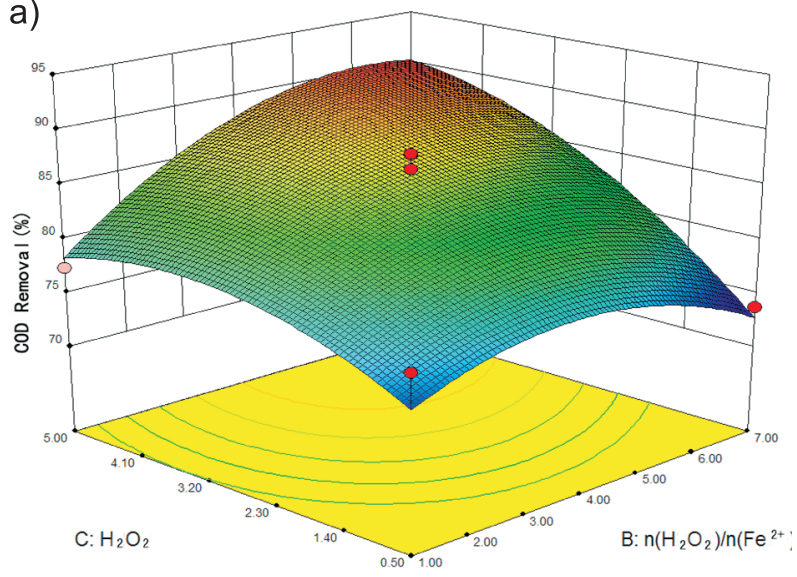

b)

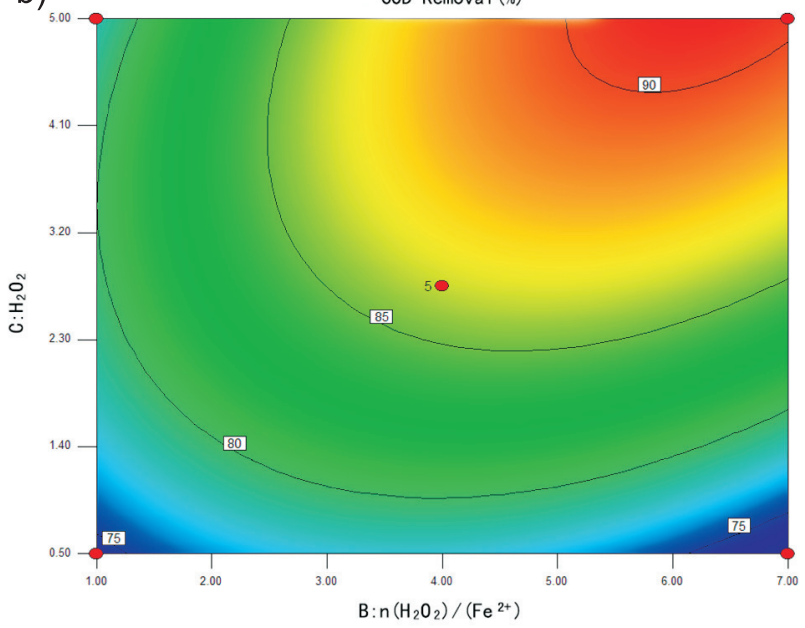

Fig. 4. Effects of $\mathrm{H}_{2} \mathrm{O}_{2}$ a) and $\left.n\left(\mathrm{H}_{2} \mathrm{O}_{2}\right) / n(\mathrm{Fe} 2+) b\right)$ as well as their interaction on $\mathrm{COD}$ removal rate.

and excessive $\mathrm{H}_{2} \mathrm{O}_{2}$ cannot increase the COD removal rate. The COD removal rate also increases firstly and then tends to be flat as $n\left(\mathrm{H}_{2} \mathrm{O}_{2}\right) / \mathrm{n}\left(\mathrm{Fe}^{2+}\right)$ increases. This is because in the Fenton reaction process the hydroxyl radicals are produced by $\mathrm{H}_{2} \mathrm{O}_{2}$ reacting with $\mathrm{Fe}^{2+}$.

Although $\cdot \mathrm{OH}$ increased with the increase of $\mathrm{Fe}^{2+}$ and $\mathrm{H}_{2} \mathrm{O}_{2}$, the organic matter to be decomposed is limited. In addition, $\mathrm{H}_{2} \mathrm{O}_{2}$ is easy to decompose into $\mathrm{H}_{2} \mathrm{O}$ and $\mathrm{O}_{2}$ [24], so there is an optimal dosage of $\mathrm{H}_{2} \mathrm{O}_{2}$. Fig. 4 shows that the optimal dosage is 5.00. When $\mathrm{n}\left(\mathrm{H}_{2} \mathrm{O}_{2}\right) / \mathrm{n}\left(\mathrm{Fe}^{2+}\right)$ is greater than 5.00, excessive $\mathrm{H}_{2} \mathrm{O}_{2}$ can react with hydroxyl radicals and generate $\mathrm{HO}_{2}$, which has an lower oxidizability than the hydroxyl radicals, and thus the COD removal rate of won't increase unlimitedly with the increase of $\mathrm{n}\left(\mathrm{H}_{2} \mathrm{O}_{2}\right) / \mathrm{n}\left(\mathrm{Fe}^{2+}\right)$ [27].

In summary, $\mathrm{COD}$ removal can be improved significantly by increasing $\mathrm{H}_{2} \mathrm{O}_{2}$ and $\mathrm{n}\left(\mathrm{H}_{2} \mathrm{O}_{2}\right) / \mathrm{n}\left(\mathrm{Fe}^{2+}\right)$ simultaneously. Fenton reaction is the main process of removing $\mathrm{COD}$ in landfill leachate, and $\mathrm{H}_{2} \mathrm{O}_{2}$ and $\mathrm{Fe}^{2+}$ are the producers of $\cdot \mathrm{OH}$ in Fenton reaction. Increasing $\mathrm{H}_{2} \mathrm{O}_{2}$ and $\mathrm{n}\left(\mathrm{H}_{2} \mathrm{O}_{2}\right) / \mathrm{n}\left(\mathrm{Fe}^{2+}\right)$ will result in an increase of $\cdot \mathrm{OH}$ and an obvious increase of COD removal rate. When $\mathrm{H}_{2} \mathrm{O}_{2}$ and $\mathrm{n}\left(\mathrm{H}_{2} \mathrm{O}_{2}\right) / \mathrm{n}\left(\mathrm{Fe}^{2+}\right)$ increases, the COD removal rate tends to be flat. The reason is that only part of the organic matter in the landfill leachate could be oxidized and degraded by hydroxyl radicals.

\section{Optimizing Operating Conditions}

Optimization was carried out on the experimental operation parameters. The limits are PFS: $10-20 \mathrm{ml}$, $\mathrm{n}\left(\mathrm{H}_{2} \mathrm{O}_{2}\right) / \mathrm{n}\left(\mathrm{Fe}^{2+}\right): 1-7, \mathrm{H}_{2} \mathrm{O}_{2}: 0.5-5 \mathrm{ml}$, and the response value is the maximum $\mathrm{COD}$ removal rate of the landfill leachate. The main factors that limit the commercialization of Fenton coagulation is the high cost and material corrosion caused by harsh reaction conditions. Therefore, the aim of this study is to effectively degrade COD in the shortest time using the smallest consumption of oxidant in the presence of PFS, $\mathrm{n}\left(\mathrm{H}_{2} \mathrm{O}_{2}\right) / \mathrm{n}\left(\mathrm{Fe}^{2+}\right)$, and $\mathrm{H}_{2} \mathrm{O}_{2}$. Eleven optimized operating conditions have been obtained, which are shown in Table 6. As seen from Table 6, No.1 is the best operating condition as it has the minimum $\mathrm{Fe}^{2+}$ dosage. And the COD removal rate can reach up to $92.11 \%$ with PFS $20 \mathrm{ml}, \mathrm{n}\left(\mathrm{H}_{2} \mathrm{O}_{2}\right) / \mathrm{n}\left(\mathrm{Fe}^{2+}\right) 6$, and $\mathrm{H}_{2} \mathrm{O}_{2} 5 \mathrm{ml}$.

\section{Economic Analysis}

The economic analysis of treating landfill leachate with the Fenton oxidation-coagulation method is shown in Table 6. The density of landfill leachate and $\mathrm{H}_{2} \mathrm{O}_{2}$ is $1 \mathrm{~g} / \mathrm{cm}^{3}$. The unit prices of the reagents are as follows (Chinese Yuan/t, from Alibaba.com):

PFS: 1,550, $\mathrm{H}_{2} \mathrm{O}_{2}: 1,400, \mathrm{FeSO}_{4} \cdot 7 \mathrm{H}_{2} \mathrm{O}: 350 ; \mathrm{FeCl}_{3}: 3,200$.

Table 6. Optimization of testing conditions.

\begin{tabular}{|c|c|c|c|c|}
\hline Number & $\begin{array}{c}\mathrm{PFS} \\
\mathrm{ml}\end{array}$ & $\begin{array}{c}\mathrm{n}\left(\mathrm{H}_{2} \mathrm{O}_{2}\right) / \\
\mathrm{n}\left(\mathrm{Fe}^{2+}\right)\end{array}$ & $\mathrm{H}_{2} \mathrm{O}_{2} \mathrm{ml}$ & $\begin{array}{c}\text { COD } \\
\text { removal rate } \\
(\%)\end{array}$ \\
\hline 1 & 20 & 6.06 & 5 & 92.11 \\
\hline 2 & 20 & 6.11 & 5 & 92.11 \\
\hline 3 & 20 & 6.02 & 5 & 92.11 \\
\hline 4 & 20 & 5.99 & 5 & 92.11 \\
\hline 5 & 20 & 6.21 & 5 & 92.10 \\
\hline 6 & 20 & 6.09 & 4.97 & 92.09 \\
\hline 7 & 20 & 5.84 & 5 & 92.09 \\
\hline 8 & 20 & 6.36 & 5 & 92.07 \\
\hline 9 & 20 & 6.04 & 4.89 & 92.03 \\
\hline 10 & 20 & 6.09 & 4.88 & 92.03 \\
\hline 11 & 20 & 5.83 & 4.72 & 91.89 \\
\hline 12 & 20 & 5.74 & 4.72 & 91.87 \\
\hline 13 & 20 & 5.23 & 5 & 91.79 \\
\hline 14 & 20 & 6.38 & 4.71 & 91.78 \\
\hline 15 & 20 & 5.73 & 4.47 & 91.62 \\
\hline 16 & 20 & 6.16 & 4.35 & 91.39 \\
\hline
\end{tabular}




\begin{tabular}{|c|c|c|c|c|c|c|c|c|c|}
\hline 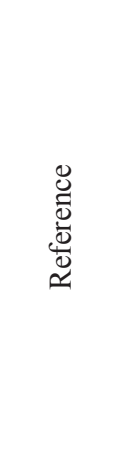 & 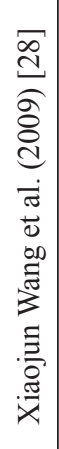 & 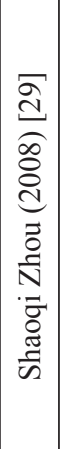 & 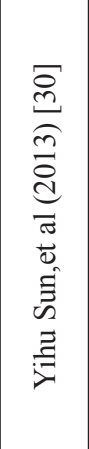 & 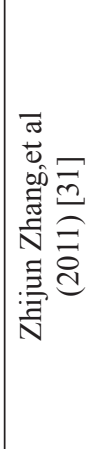 & 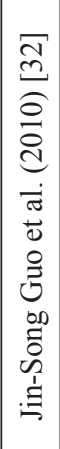 & 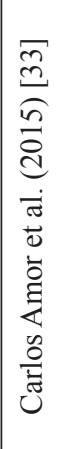 & 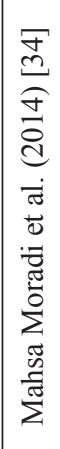 & 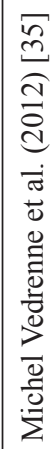 & 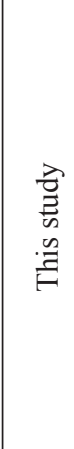 \\
\hline 蒫悉 & $\begin{array}{l}\tilde{N} \\
\text { }\end{array}$ & $\begin{array}{l}n \\
\hat{n} \\
i\end{array}$ & $\stackrel{\infty}{\oplus}$ & $\begin{array}{l}\stackrel{\forall}{f} \\
\underset{f}{+}\end{array}$ & $\begin{array}{l}0 \\
0 \\
6 \\
m\end{array}$ & ָุ. & $\frac{n}{\infty}$ & $\vec{F}$ & $\stackrel{f}{\stackrel{m}{m}}$ \\
\hline 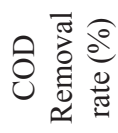 & $\mid \begin{array}{l}0 \\
0 \\
0\end{array}$ & \& & $\frac{\pi}{6}$ & ?̊? & $\frac{m}{\alpha}$ & $\infty$ & I & $\begin{array}{l}0 \\
\dot{6}\end{array}$ & $\bar{\Omega}$ \\
\hline 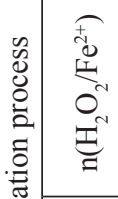 & $\stackrel{\sim}{\Im}$ & - & $\begin{array}{l}\infty \\
\infty \\
i\end{array}$ & $\nabla$ & $\underset{\text { fr }}{\text { in }}$ & $\begin{array}{l}a \\
\dot{\alpha} \\
\dot{b}\end{array}$ & $\sim$ & $\stackrel{\Xi}{\Xi}$ & 0 \\
\hline 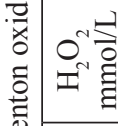 & $\ddot{n}$ & 0 & $\stackrel{\infty}{\stackrel{\infty}{\sim}}$ & $\stackrel{+}{\sim}$ & $\stackrel{0}{I}$ & 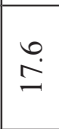 & ¿ & $\begin{array}{l}n \\
\infty \\
\infty\end{array}$ & 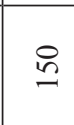 \\
\hline$\frac{\pi}{2}$ & $m$ & ' & $\tilde{n}$ & ' & $m$ & $m$ & $n$ & $m$ & $m$ \\
\hline 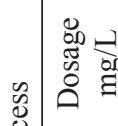 & 8 & है & $\stackrel{\varrho}{=}$ & 号 & $\stackrel{\infty}{\infty}$ & $\underset{8}{8}$ & $\begin{array}{l}8 \\
\stackrel{2}{n} \\
-1\end{array}$ & : & $\overbrace{}^{2}$ \\
\hline 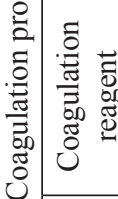 & $\frac{\pi}{2}$ & $\mid \begin{array}{l}\infty \\
\frac{\pi}{2}\end{array}$ & $\frac{\omega}{\omega}$ & 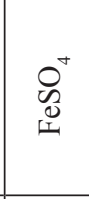 & $\begin{array}{l}\infty \\
L \\
L\end{array}$ & 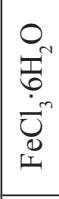 & $\begin{array}{c}\tilde{D}^{n} \\
\omega\end{array}$ & 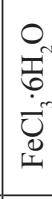 & $\frac{1}{2}$ \\
\hline$\stackrel{\square}{2}$ & in & in & $\begin{array}{l}8 \\
\text { in }\end{array}$ & ' & in & in & $r$ & ' & $n$ \\
\hline 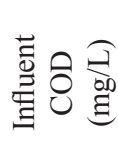 & 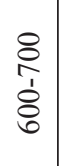 & ơ & $\begin{array}{l}8 \\
\stackrel{0}{n} \\
\sim\end{array}$ & $\begin{array}{l}\hat{6} \\
\text { in }\end{array}$ & $\begin{array}{l}n \\
\stackrel{n}{7}\end{array}$ & $\begin{array}{l}8 \\
2 \\
\text { in }\end{array}$ & $\begin{array}{l}8 \\
0 \\
0 \\
0 \\
0 \\
0 \\
1 \\
=\end{array}$ & 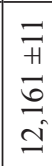 & \& \\
\hline 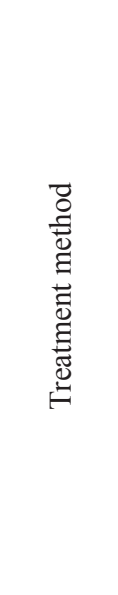 & 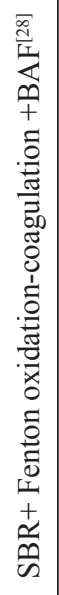 & 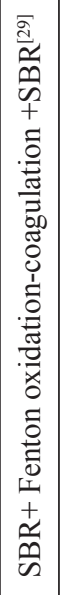 & 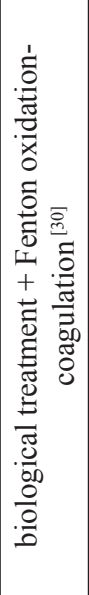 & 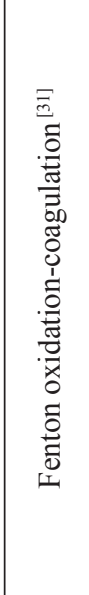 & 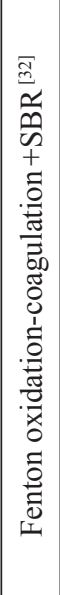 & 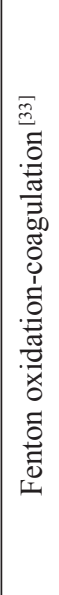 & 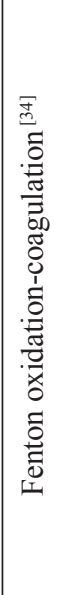 & 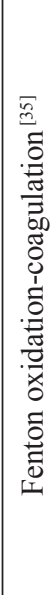 & 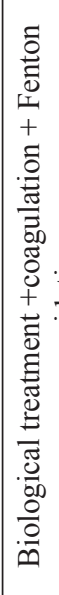 \\
\hline 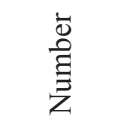 & - & $N$ & $m$ & ナ & in & 0 & $r$ & $\infty$ & $a$ \\
\hline
\end{tabular}

As seen from Table 7:

1. Treating landfill leachate with Fenton oxidationcoagulation method and the cost is greatly influenced by water quality. Great differences can be found in the landfill leachate with similar COD concentrations and different ages.

2. When the cost of the Fenton oxidation-coagulation method is low, the COD removal rate is usually not ideally high. The poor water quality can't satisfy the requirement, resulting in a high load of subsequent processing technique and high total operational cost.

3. Treating landfill leachate with a concentration of 2,000 $\mathrm{mg} / \mathrm{l}$ with Fenton oxidation-coagulation method, the cost in this study reaches the lowest while the COD removal rate is above $90 \%$. The increase of PFS leads to optimization of the coagulation effect and reduction of consumption of the Fenton reagent, as well as the treatment cost.

\section{Conclusions}

1. Treating landfill leachate using the Fenton oxidationcoagulation method and fitting the equation of $\mathrm{COD}$ removal rate is obtained by BBD tests as well as RSM with PFS, $\mathrm{n}\left(\mathrm{H}_{2} \mathrm{O}_{2}\right) / \mathrm{n}\left(\mathrm{Fe}^{2+}\right)$, and $\mathrm{H}_{2} \mathrm{O}_{2}$ as influencing factors. The fitting equation has a high significance and sensitivity and the predicted results are close to the real measured data. Compared with the experimental results, the errors in the prediction of COD removal rate is less than $\pm 5 \%$.

2. Results of the ANONA analysis of the fitting equation show that factors influencing the COD removal rate are: $\mathrm{H}_{2} \mathrm{O}_{2}>\mathrm{n}\left(\mathrm{H}_{2} \mathrm{O}_{2}\right) / n\left(\mathrm{Fe}^{2+}\right)>$ PFS. The increase of $\mathrm{H}_{2} \mathrm{O}_{2}$ dosage and $\mathrm{n}\left(\mathrm{H}_{2} \mathrm{O}_{2}\right) / \mathrm{n}\left(\mathrm{Fe}^{2+}\right)$ is more effective in degradation of the organic matter, while the increase of PFS is not.

3. For biochemical effluent of landfill leachate with a concentration of around 2,000 mg/l, the optimum operating conditions for Fenton oxidation-coagulation are (for one liter landfill leachate): PFS-67 ml $(0.05 \mathrm{~g} / \mathrm{L}), \mathrm{H}_{2} \mathrm{O}_{2}(30 \%)-17 \mathrm{ml}$, and $\mathrm{n}\left(\mathrm{H}_{2} \mathrm{O}_{2}\right) / \mathrm{n}\left(\mathrm{Fe}^{2+}\right)-6$, and the COD removal rate can reach as high as $92.11 \%$.

\section{Acknowledgements}

This work was supported by the Natural Science Foundation of China (grant No. 21167003) and the Bureau of science and technology in Nanning, Guangxi (grant No. 20131416).

\section{References}

1. VEDRENNE M., VASQUEZ-MEDRANO R., PRATOGARCIA D., et al. Characterization and detoxification of a mature landfill leachate using a combined coagulationflocculation/photo Fenton treatment[J]. Journal of Hazardous Materials, 205, 208, 2012. 
2. ZHANG H., WU X., LI X. Oxidation and coagulation removal of COD from landfill leachate by Fered-Fenton process[J]. Chemical Engineering Journal, 210, 188, 2012 [In Chinese].

3. KANGGK S.P. Characterization of humic substances present in landfill with different landfill ages and its implications[J]. Water Research, 36, 4023, 2002.

4. SINGH S.K., TANG W.Z. Statistical analysis of optimum Fenton oxidation conditions for landfill leachate treatment $[\mathrm{J}]$. Waste Management, 33 (1), 81, 2013.

5. LOPEZ A., PAGANOM, VOLPE A., et a1. Fenton's pretreatment ofmature landfill leachate[J]. Chemosphere, (54), 1005, 2004

6. OZTURK I., ALTINBASM, KOYUNCU I., et a1. Advanced physic-chemical treatment experiences on young municipal landfill leachates[J]. Waste Management, (23), 441, 2003.

7. FRASCARI D., BRONZINI F., GIORDANO G., et a1. Long-term characterization, lagoon treatment and migration potential of landfill leachate: a case study in an active Italian landfill [J]. Chemosphere, 554, 335, 2004.

8. WU J.J., WU C., MA H., et a1. Treatment of landfill leachate by ozone-based advanced oxidation processes[J]. Chemosphere, 54, 997, 2004.

9. TABET K., MOULIN P., VILOMET J.D.A., et a1. Purification of landfill leachate with membrane processes: preliminary studies for an industrial plant $[J]$. Separate Science Technology, 37, 1041, 2007.

10. MAHMUD K., HOSSAIN M.D., SHAMS S. Different treatment strategies for highly polluted landfill leachate in developing countries[J]. Waste Management, 32 (11), 2096, 2012.

11. TAINA H. HOILIJOLI, et al. Rintala. Nitrification of anaerobically pretreated municipal landfill leachate at low temperature [J]. Water Research, 34 (5), 1435, 2000.

12. ORKUN M.O., KULEYIN A. Treatment performance evaluation of chemical oxygen demand from landfill leachate by electro-coagulation and electro-Fenton technique[J]. Environmental Progress \& Sustainable Energy, 31 (1), 59, 2012.

13. LAK M.G., SABOUR M.R., AMIRI A., et al. Application of quadratic regression model for Fenton treatment of municipal landfill leachate[J]. Waste Management, 32 (10), 1895, 2012

14. PAPAPHILIPPOU P.C., YIANNAPAS C., POLITI M., et al. Sequential coagulation-flocculation, solvent extraction and photo-Fenton oxidation for the valorization and treatment of olive mill effluent[J]. Chemical Engineering Journal, 224, 82, 2013.

15. BOUMECHHOUR F., RABAH K., LAMINE C., et al. Treatment of landfill leachate using Fenton process and coagulation/flocculation[J]. Water and Environment Journal, 27 (1), 114, 2013.

16. VERMA A.K., DASH R.R., BHUNIA P. A review on chemical coagulation/flocculation technologies for removal of colour from textile wastewaters[J]. Journal of Environmental Management, 93 (1), 154, 2012.

17. GHANBARZADEH L.M., SABOUR M.R., AMIRI A., et al. Application of quadratic regression model for Fenton treatment of municipal landfill leachate $[\mathrm{J}]$. Waste Management, 32 (10), 1895, 2012.

18. CHEN H., PENG W. Rapid Determination of COD_(Cr) by Microwave Sealed Digestion Method[J]. Chongqing Environmentalence, 1996

19. RODRÍGUEZ-CHUECA J., MORALES M., MOSTEO R., et al. Inactivation of Enterococcus faecalis, Pseudomonas aeruginosa and Escherichia coli present in treated urban wastewater by coagulation-flocculation and photo-Fenton processes [J]. Photochemical \& Photobiological Sciences, 12 (5), 864, 2013.

20. UPADHYAY A.P., MISTRY N.J. Feasibility of combined Fenton \& coagulation method for the treatment of pesticides waste water[C]//nternational Journal of Engineering Research and Technology. ESRSA Publications, 1 (3), 1, 2012.

21. MORADI M., GHANBARI F. Application of response surface method for coagulation process in leachate treatment as pretreatment for Fenton process: Biodegradability improvement $[\mathrm{J}]$. Journal of Water Process Engineering, 4, 67, 2014.

22. ZAZOULI M.A., YOUSEFI Z., ESLAMI A., et al. Municipal solid waste landfill leachate treatment by Fenton, photo-fenton and Fenton-like processes: effect of some variables[J]. Iranian Journal of Environmental Health Science \& Engineering, 9, 3, 2012.

23. YING D., PENG J., XU X., et al. Treatment of mature landfill leachate by internal micro-electrolysis integrated with coagulation: a comparative study on a novel sequencing batch reactor based on zero valent iron[J]. Journal of Hazardous Materials, 229, 426, 2012.

24. AMOR C., DE TORRES-SOCÍAS E., PERES J.A., et al. Mature landfill leachate treatment by coagulation/ flocculation combined with Fenton and solar photo-Fenton processes[J]. Journal of Hazardous Materials, 286, 261, 2015.

25. LIU KEWAN. Studies on phosphorus removal in municipal wastewater treatment by polysilicate composite flocculant [D]. Chongqing University, 2005 [In Chinese].

26. CHYS M., DECLERCK W., AUDENAERT W., et al. $\mathrm{UV} / \mathrm{H}_{2} \mathrm{O}_{2}, \mathrm{O}_{3}$ and (photo-) Fenton as treatment prior to granular activated carbon filtration of biologically stabilized landfill leachate[J]. Journal of Chemical Technology and Biotechnology, 90 (3), 525, 2015.

27. KRITZER M.F., MCLAUGHLIN P.J., SMIRLIS T., et al. Gonadectomy impairs T-maze acquisition in adult male rats [J]. Hormones \& Behavior, 39 (2), 167, 2001.

28. XIAOJUN WANG, SILI CHEN, XIAOYANG GU, KAIYAN WANG Pilot study on the advanced treatment of landfill leachate using a combined coagulation, Fenton oxidation and biological aerated filter process, 29 (4), 1354, 2009 [In Chinese].

29. ZHOU SHAOQI, ZHONG HONGCHUN, HUYONGCHUN Fenton Oxidation Cooperated with PFS Coagulation and SBR for Deepen Treating a Mature Landfill Leachate [J]. Environmental Science, 29 (8), 2201, 2008 [In Chinese].

30. SUN YIHU, SUN TIEGANG, LI XIAOMING, et al. Color removal in aged landfill leachate by process of coagulation-flocculation and Fenton [J]. Chinese Journal of Environmental Engineering, 7 (6), 2116, 2013 [In Chinese].

31. ZHANG ZHI-JUN, QIN JING, LIU DONG-FEI Treatment of Landfill Leachate by Coagulation- Fenton Process [J]. Journal of Changzhou University (Natural Science Edition), 23 (1), 39, 2011 [In Chinese].

32. JIN-SONG GUO, ABDULHUSSAIN A. ABBAS, YOUPENG CHEN, ZHI-PING LIU, FANG FANG, PENG CHEN Treatment of landfill leachate using a combined stripping, Fenton, SBR, and coagulation process, Journal of Hazardous Materials. 178 (1-3), 699, 2009.

33. CARLOS AMOR, ESTEFANÍA DE TORRES-SOCÍAS, JOSÉ A. PERES, MANUEL I. MALDONADO, ISABEL OLLER, SIXTO MALATO, MARCO S. LUCAS, MATURE Landfill leachate treatment by coagulation/flocculation 
combined with Fenton and solar photo-Fenton processes, Journal of Hazardous Materials, 286, 261, 2015.

34. MAHSA MORADI, FARSHID GHANBARI Application of response surface method for coagulation process in leachate treatment as pretreatment for Fenton process: Biodegradability improvement, Journal of Water Process Engineering, 4, 67, 2014.
35. MICHEL VEDRENNE, RUBEN VASQUEZ-MEDRANO, DORIAN PRATO-GARCIA, BERNARDO A. FRONTANA-URIBE, JORGE G. IBANEZ Characterization and detoxification of a mature landfill leachate using a combined coagulation-flocculation/photo Fenton treatment, Journal of Hazardous Materials, 205-206, 208, 2012. 